\title{
Mülteci Çocukların İlköğretime Uyum Süreçleri: Tekirdağ İlinin Bir Okulundaki Öğretmenlerin ve Yöneticilerin Deneyimleri *
}

\section{Primary School Adaptation Process Of Refugee Children: Experiences of Administrators and Teachers in a School at Tekirdă̆ Province}

\author{
Caner Dinler ${ }^{\mathrm{a}, * *}$, Özge Hacıfazlıoğlu ${ }^{\mathrm{b}}$
}

${ }^{a}$ Öğrt. ve Doktora Öğrencisi, İstanbul Okan Üniversitesi, Lisansüstü Eğitim Enstitüsü, Eğitim Yönetimi ve Denetimi ABD, İstanbul/Türkiye. ORCID ID: 0000-0002-7302-3938

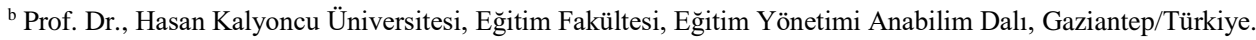
ORCID ID:0000-0002-5040-229X

\section{MAKALE BİLGİSİ}

Makale Geçmişi:

Başvuru tarihi: 07 Ocak 2020

Düzeltme tarihi: 15 Mayıs 2020

Kabul tarihi: 22 Mayıs 2020

Anahtar Kelimeler:

Mülteci Öğrenciler

Okula Uyum

Uyum Süreci Stratejileri
ÖZ

$\mathrm{Bu}$ araştırmada, Suriyeli mülteci öğrencilerin okula uyum süreçlerine ilişkin öğretmenlerin ve okul yöneticilerinin deneyimleri ele alınmaktadır. Bu araştırma, nitel araştırma yöntemlerinden olgubilim temel alınarak yürütülmüştür. Araştırmada amaçlı örneklem yöntemlerinden kolay ulaşılabilir durum örneklemesi kullanılmıştır. Araştırmanın çalışma grubunu, Tekirdağ ilinin Marmara Ereğlisi ilçesine bağlı, Suriyeli mülteci öğrencilerin sayılarının fazla olduğu bir ilkokulda görev yapan 2 yönetici ve 11 öğretmen oluşturmaktadır. Veri toplama aracı olarak yarı yapılandırılmış görüşme tekniği kullanılmıştır. İçerik analizi kullanılarak elde edilen verilerden temalar ve alt temalar oluşturulmuştur. "Okula Uyum: Öğretmenlerin ve Öğrencilerin Sorunları" ve "Uyum Sürecinde Kullanılan Stratejiler" olmak üzere iki temada veriler sınıflandırılmıştır. Yapılan bu sınıflandırmalar neticesinde Suriyeli mülteci öğrencilerin okula uyum süreçlerinde öğretmenlerin ve Suriyeli mülteci öğrencilerin, dil ve iletişim sorunlarıyla, dışlanma eğilimine ilişkin sorunlarla, Suriyeli öğrencilere özel birleştirilmiş sınıfta eğitim verilmesinden kaynaklanan sorunlarla karşılaştıkları; uyum sürecini kolaylaştırmak için ise öğretmenler ve yöneticiler tarafindan, akran mentörlüğü, deneyimli Suriyeli öğrencilerin mentörlüğü, öğretmen mentörlüğü ve velilere mentörlük stratejilerinin kullanıldığı ortaya çıkmıştır.

\section{A B S T R A C T}

In this study, the experiences of teachers and school administrators regarding Syrian refugee students' adaptation processes are discussed. The study was carried out on the basis of case study analysis which is the one of the qualitative research methods. The convenience sampling were used in the study. The study group consists of 2 administrators and 11 teachers, whom working in a elementary school in the district of Marmara Ereğlisi of Tekirdağ province where the number of Syrian refugee students is enormously high. Semi-structured interview technique was used as a data collection appliance. Sub-themes and themes were created from the data by using content analysis. Data were classified classified into two themes: "Integration to School: Problems of Teachers and Students" and "Used Strategies in the Integration Process". As a result of these classifications, Syrian refugee students faced problems related to language and communication problems, tendency to be excluded, and the problems arising from the education of Syrian students in a multigrade class; To facilitate the adaptation process, it was revealed that teachers and administrators use peer mentoring, mentoring of experienced Syrian students, teacher mentoring, and mentoring strategies to parents.

\section{Giriș}

İnsani değerleri kazanımında en önemli araç olan eğitimden beklenen verimliliğin alınabilmesi, öğrencilerin okula uyum sürecinin sağlıklı bir șekilde gerçekleșebilmesiyle doğru orantılıdır. Okula uyum sağlayan öğrencilerin tedirginliği, endişe ve stresi ortadan kalkar. Öğrencinin kendisine olan

\footnotetext{
* Bu çalışmanın ilk hali 12. Uluslararası Eğitim Yönetimi Kongresi 11-13 Mayıs 2017 tarihinde Başkent Üniversitesinde sözlü bildiri olarak sunulmuştur.

** Sorumlu yazar/Corresponding author.

e-posta: caner_36di@hotmail.com
} 
güveni artar; duygusal, zihinsel ve fiziksel gelişimi olumlu yönde etkilenir. Uyum sürecinin en önemli sacayağını öğretmenler oluşturmaktadır. Aynı dili konuşan, aynı vatanı ve kültürü paylaşan öğretmen ve öğrenciler arasında, doğuştan gelen bu ortak değerler gizli sözleşmeler mahiyetindedir. $\mathrm{Bu}$ ittifak sayesinde okula uyum süreci kolaylaşmaktadır.

Okula uyum kavramı çocuğun girdiği yeni ortamda gösterdiği sosyal, davranışsal ve akademik bir tepki olarak ele alınmaktadır. Sosyal ile bilişsel yeteneklerde yaşanılan zorluklar çocukların okula uyum sürecinde olumsuz etki birakabilmektedir (Gresham ve Elliott, 1987; Ladd ve Price, 1987). Okula uyum kendi içinde zorlukları barındıran bir dönem olmakla beraber dezavantajlı çocuklar için bu durum içinden çıkılması zor bir kısır döngü de oluşturabilmektedir. Çocuk için okula başlama süreci sosyal, bilişsel, fiziksel ve duygusal uyum gerektirmekte olan zorlu bir süreci ifade eder ve gelecek yılları için kritik önemi olan bir dönemdir (Ladd ve Price, 1987).

Yakın zamanda Suriye'de yaşanmış olan iç savaş neticesinde ülkemize göç eden Suriyeli çocukların eğitiminde ortaya çıkan en önemli sorunlardan birini okula uyum süreci oluşturmaktadır. Rakamlar incelendiğinde, nicel olarak Suriyeli öğrenci sayısının fazlalığı öğretmenlerin ve okul yöneticilerinin yaşadıkları sorunları yansıtmaktadır. 2016 yılının başında Türkiye 2.715.789 kişiyle en çok Suriyeli mülteci barındıran ülke konumundadır. $\mathrm{Bu}$ nüfusun yarısı da çocuklardan oluşmaktadır (UNICEF, 2016). 2011 yılından itibaren eğitime erişim oranı artmakla birlikte Millî Eğitim Bakanlığı (MEB) kaynaklarına göre 2016 yılı okula erişim oranları incelendiğinde, eğitim çağındaki çocukların yarısından fazlasının halen erişim sıkıntısı yaşadığı görülmektedir (Emin, 2016). Öğrenim hakk1, Çocuk Hakları Sözleşmesinde garanti altına alınmış ve buna ek olarak ilgili devletlerde eğitim gören çocukların hakkı kabul edilerek firsat eşitliği temel alınıp temel eğitimin herkes için ücretsiz ve zorunlu hale getirilmesi amaçlanmıştır. Bununla beraber "çocuğun kişiliğinin, zihinsel ve bedensel yeteneklerinin mümkün olduğunca geliştirilmesini, insan haklarına ve temel özgürlüklere saygısının arttırılmasını, kültürel kimliğine, dil ve diğerleri ile çocuğun geldiği ülkenin ulusal değerlerine ve kendisininkinden farklı uygarlıklara saygısının pekiştirilmesini, anlayış, hoşgörü, eşitlik gibi hususlarda sorumluluk üstlenmesini ve doğal çevreye saygısının geliştirilmesini” de amaçlamaktadır (Odman, 2008, s. 143-144). Bu haklara rağmen dünyadaki yaşanan sosyoekonomik problemler ve savaş gibi olumsuz durumlardan çocuklar en kötü şekilde etkilenen grup olarak görülmektedir. Zor koşullar altında çocukların temel ihtiyaçları temin edilememekte ve bu çocuklar çeşitli haksızlıklara maruz kalmaktadır. Mutlu ve Kırımsoy'a (2016) göre benzer sorunlar Türkiye'deki mülteci çocuklarda da yaşanmaktadır.

ÇOÇA'nın (2015) yaptığı araştırmaya göre okula gitme hakkını kullanamayan Suriyeli mülteci öğrencilerin diğer çocuklardan daha fazla kötü muamele ve istismara uğrama riski altında bulunduğu, travma sonrası stres bozukluğu belirtilerini (stres, endişe, tedirginlik, umutsuzluk gibi) daha çok gösterdiği, fiziksel ve psikolojik gelişme evrelerini tamamlayamadıkları görülmektedir (ÇOÇA, 2015).
Suriyeli mülteci öğrencilerin "kayıp kuşak" olma riski karşısında Türkiye'de MEB tarafından 2013 yılından itibaren çeşitli çalışmalar yürütülmektedir. "Eylül 2014'te yayımlanan yabancıların eğitime erişimine ilişkin MEB genelgesi (No: 2014/21), geçici koruma altındaki yabancıların her ildeki il milli eğitim müdürlüğü tarafından denetlenen okullar ve geçici eğitim merkezleri tarafından sağlanan eğitim hizmetlerine erişimini belirli bir standarda bağlamış ve güvence altına almıştır" (UNCHR, 2016). Yeni düzenlemeler ile birlikte Suriyeli mülteci çocuklara eğitime erişme sürecindeki hakları verilse de süreç içinde ortaya çıkan sorunlar, okulda öğrenime devam etme konusunda engeller doğurabilmektedir.

ÇOÇA (2015) tarafından yürütülmüş çalışmalarda, Suriyeli çocuklara yönelik sorunların başında "dil" engelinin olduğu görülmektedir. Bunun yanında toplumla uyum konusunda da zorluklar işaret edilmektedir. Bu zorlukların yanında ekonomik sıkıntılarla ilişkili olarak yaşanan eğitim öğretim kaynaklarındaki sıkıntılar da adı geçen çalışmada dile getirilmektedir.

Sınıflarına farklı kültürlerden gelen öğrencilerle beraber ilk zamanlarda zorluklar yaşayan öğretmenler, bu sorunları çözmeye yönelik olarak kendilerine özgü çözüm yolları aramışlardır. Suriyeli mülteci çocuklarla ilgili çalışmalar son yıllarda gerek uygulamacılar gerekse araştırmacılar tarafından önemle ele alınan bir konu haline gelmiştir. Ancak çocuklarla beraber bu zorlukları yaşayan öğretmenler tarafından "yaşanmış deneyimleri” aktaran derinlikli çalışmaların sayısı sınırlıdır. Bu bağlamda; bu araştırma, okul yöneticilerine ve öğretmenlere mülteci çocukların okulda uyumuna yönelik uygulama odaklı özgün bir bakış açısı sağlayacağının düşünülmesi açısından önemlidir. $\mathrm{Bu}$ çalışmanın amacı, Suriyeli mülteci öğrencilerin okula uyum süreçlerine ilişkin öğretmenlerin ve okul yöneticilerinin deneyimlerinin incelenmesidir. Suriyeli mülteci öğrencilerin okula uyum süreçlerinde öğretmenlerin ve okul yöneticilerinin yaşadıkları sorunlar ve bu sorunların üstesinden gelmeye yönelik kullandıkları stratejiler aktarılmıştır.

Araştırma çerçevesinde aşağıdaki sorulara cevap aranmıştır:

-Uyum sürecinde öğretmenlerin ve yöneticilerin karşılaştıkları sorunlar nelerdir?

-Öğretmenler ve yöneticiler okula uyum sürecini sağlamada ne tür stratejiler kullanmıştır?

\section{Yöntem}

Bu bölümde; araştırma deseninden, çalışma grubundan, veri toplama aracindan, verilerin analizi ve yorumlanması sürecinden bahsedilmiştir.

\subsection{Araştırma Deseni}

$\mathrm{Bu}$ araştırmada; nitel araştırma yaklaşımlarından durum çalışması yöntemi kullanılmıştır Araştırmada "insan deneyimlerine" dayanan nitel veri yöntemi kullanılmıştır. Nitel veri, insanların "algılarını, varsayımlarını, önyargılarını" (Van Maanen, 1977) ve bunların sosyal yaşamla olan ilişkilerini açıklayarak insanların yaşamlarındaki "olaylara, süreçlere ve yapılara" yönelik düşüncelerini ortaya çıkarmak için oldukça uygundur (Miles ve Huberman, 1994). Nitel durum çalışmasının en 
büyük özelliği ise "bir ya da birkaç durumun derinlemesine araştırılması"dır (Yıldırım ve Şimşek, 2008, s. 73). Bu bağlamda; bu araştırmada, Suriyeli mülteci öğrencilerin yaşadıkları problemlerle ilgili olarak öğretmenlerin ve yöneticilerin deneyimlerinin gerçekçi ve bütüncül bir yaklaşımla derinlemesine incelenmesi amaçlandığı için nitel araştırma yaklaşımlarından durum çalışması yöntemi kullanılmıştır.

\section{2. Çalışma Grubu}

Araştırmanın çalışma grubu, Tekirdağ ilinin Marmara Ereğlisi ilçesine bağlı bir ilkokulda görev yapan 2 yönetici ve 11 öğretmenden oluşmaktadır. Tablo 1'de araştırmaya katılan öğretmenlerin demografik özellikleri verilmiştir.

Tablo 1. Katılımcıların, Branşları, Cinsiyetleri, Yaşları, Kıdemleri ve Eğitim Durumları Tablosu

\begin{tabular}{lcccc}
\hline Kod Adı & Cinsiyet & Yaş & Kıdem & $\begin{array}{c}\text { Eğitim } \\
\text { Durumu }\end{array}$ \\
\hline Billur* & K1z & 39 & 18 & Lisans \\
Esat** & Erkek & 50 & 27 & Lisans \\
Gülhanım*** & K1z & 35 & 14 & Lisans \\
Zeynep*** & K1z & 38 & 17 & Lisans \\
Niyazi*** & Erkek & 30 & 7 & Lisans \\
Aslan*** & Erkek & 56 & 28 & Lisans \\
Tahir*** & Erkek & 55 & 31 & Lisans \\
Yusuf*** & Erkek & 36 & 14 & Y. Lis. \\
Güler*** & K1z & 40 & 18 & Lisans \\
Melike*** & K1z & 31 & 8 & Lisans \\
Songül*** & K1z & 45 & 23 & Lisans \\
Fevzi*** & Erkek & 37 & 15 & Lisans \\
Türkan*** & K1z & 34 & 11 & Lisans \\
\hline Müdür & & & & \\
$* *$ Müdür Yardımcısı & & & \\
$* * *$ Sinıf Öğretmeni & & &
\end{tabular}

Araştırmada çalışma grubu belirlenirken, araştırmaya uygun ve rahat ulaşılabilir bir örneklem seçildiği için amaçlı örneklem yöntemlerinden "kolay ulaşılabilir durum örneklemesi” kullanılmıştır. "Bu örnekleme yöntemi araştırmaya hız ve pratik kazandırır. Çünkü bu yöntemde araştırmacı, yakın olan ve erişilmesi kolay olan bir durumu seçer" (Yıldırım ve Şimşek, 2008, s. 123). Ayrıca araştırma grubu gönüllülük esasına göre belirlenerek araştırmaya katılan öğretmenlerin ve yöneticilerin gönüllülüklerini beyan ettikleri gönüllülük sözleşmesi imzalatılmış olup katılımcıların isimlerinin yerine kod isimler kullanılmıştır.

\subsection{Veri Toplama Arac1}

$\mathrm{Bu}$ araştırmada yarı yapılandırılmış görüşme tekniği kullanılarak veriler toplanmıştır. Görüşme formu hazırlanırken literatürden ve uzman görüşlerinden yararlanılmıştır. İlk aşamada taslak olarak hazırlanan bu formun geliştirilmesinde nitel araştırmalar konusunda yetkin; biri profesör doktor, biri doktor öğretim üyesi ve dördü doktora öğrencisi olmak üzere toplam altı uzmanın görüşüne başvurulmuştur. Uzmanlar tarafından görüşme formunda yer alan bazı soruların yönlendirici ifadeler içerdiği ifade edildiği için bu soruların sayısında herhangi bir değişiklik yapılmadan sadece ifade şekli açısından yeniden düzeltilmesi hususundaki dönütlerine istinaden araştırmacı tarafından bu düzeltmeler yapılmıştır.

\subsection{Verilerin Toplanması}

Soruların açık ve anlaşılır olup olmadığını değerlendirmek üzere çalışma grubu dışında 4 öğretmen ile pilot uygulama yapılmıştır. Pilot uygulamadan elde edilen bilgi ve tecrübeler sonucunda görüşme formu tekrar gözden geçirilmiş ve yine aynı altı uzmanın görüşüne başvurularak bir sorunun ifade şekli yeniden düzenlenerek yarı yapılandırılmış görüşme formu asıl araştırma için uygulanır hâle getirilmiştir. Görüşmelere başlamadan önce, konu hakkında yerli ve yabancı alan yazın taraması yapılmıştır. Alan yazın taraması ile çalışmanın kuramsal temelleri oluşturulup konu hakkında kapsamlı bilgilere ulaşıldıktan sonra okul yöneticileriyle ve öğretmenlerle görüşülmüştür.

Görüşme esnasında katılımcılara şu sorular yöneltilmiştir:

1. Suriyeli mülteci öğrencilere ve ailelerine ilişkin deneyimleriniz nasıldır?

2. Uyum sürecinde sizlerin ve mülteci öğrencilerin karşılaştığ1 sorunlar nelerdir? Deneyimlerinizden kesitler aktarabilir misiniz?

3. Öğrencilerinizin okula uyum sürecini kolaylaştırmak için kullandığınız stratejiler nelerdir? Deneyimlerinizden kesitler aktarabilir misiniz?

4. Suriyeli mülteci öğrencilerle yaşadığınız, unutamadığınız bir olay var mi? Deneyimlerinizden kesitler aktarabilir misiniz?

Görüşmeler sırasında veri kaybı yaşamamak için kayıt cihazından yararlanılmıştır. Görüşmelerde kayıt cihazı kullanılacağı katılımcılara söylenmiştir. Bununla beraber, yapılan kayıtların katılımcılar tarafindan dinlenebileceği, istendiği takdirde kayıtlardaki ifadelerin katılımcının isteğine bağlı olarak kısmen çıkarılabileceği ya da kaydın tamamen silinebileceği belirtilmiştir. Bu sayede kayıt cihazı kullanımının katılımcılar üzerinde oluşturabileceği tedirginlik giderilmeye çalışılmıştır. $\mathrm{Bu}$ çalışmada, araştırmaya katılanların kimliklerini korumak için kod isimler kullanılmıştır. Bu çalışma, Ekim 2016 tarihinde başlamış ve Mayıs 2017 tarihinde tamamlanmıştır.

\subsection{Verilerin Analizi}

Marshall ve Rossman (1999) tarafından öne sürülen analiz süreci beş kategori referans alınarak yürütülmüştür: "a) verilerin organize edilmesi; b) temaların ve kategorilerin tanımlanması; c) ortaya çıkan hipotezin veriler ile test edilmesi; d) verilere ilişkin alternatif açıklamaların aranması ve e) raporun yazılması" (Akt. Hacıfazlığlu, 2010, s. 2224).

Tema Oluşturma Aşaması: Araştırmacı, Merriam (1988) Miles ve Huberman'1 (1994) ve Yıldırım ve Şimşek'i (2008, s. 228) içerik analizi oluştururken referans alarak elde edilen kavramları birbirleriyle belirli bir tema altında sınıflandırmıştır. Kavramların incelemesi sonucunda alt temaların birbirleriyle olan ilişkileri ortaya çıkarılmış ve bu ilişkiler daha üst bir tema ile açıklanmıştır. Veriler daha önceden hazırlanmış olan tablolara aktarılmış, her bir katılımcının karşısına ilgili tema ve deneyimi yansıtılmıştır. Araştırmac1, görüşmelerin yürütüldüğü ve analiz edildiği süre boyunca meslektaşlarından geri bildirim almıştır. Araştırmacı, analiz sonuçlarını altı alan uzmanıyla beraber kasım ve aralık (2016) aylarında birer saatlik oturumlarda 4 
kez tartışmıştır. Bu oturumlar da kayıt altına alınmış ve bu kayitlar verilerin düzenlenmesinde referans olarak kullanılmıştır. Temaların analizi ve yorumlanması sırasında da alan uzmanlarından benzer şekilde görüşler alınmış olup 3 değerlendirme oturumu yapılarak ortaya çıkan tema ve alt temalara son şekli verilmiştir.

Verilerin Sunulması: Suriyeli mülteci öğrencilerin okula uyum süreçlerine ilişkin olarak öğretmenlerin ve okul yöneticilerinin deneyimlerinin incelenmesine yönelik hikâyelerine odaklanılmıştır. Analizlerin devamı niteliğinde "hikâye etme" şeklinde (narrative) özetler yapılmıştır. Maxwell'e (1996) göre, "kisa anekdotlar" (thumbnail sketches), anlatanın bakış açısına göre konuyla alakalı ilginç noktaların seçilerek yansıtılmasıdır. Araştırma bulgularının analizi sırasında yöneticilerin ve öğretmenlerin kendi ifadelerine odaklanılarak, kullandıkları kelimeler ve ifadeler titizlikle incelenmiştir. Hikâye şeklinde düzenlenen görüşme özetlerinde Seidman'ın (1998) kullandığı yöntemden yararlanılarak, görüşülen katılımcının deneyimlerinin, inançlarının ve görüşlerinin yansıtılmasına çalışılmıştır. Toplanan veriler araştırmacı tarafından detaylı bir biçimde düzenlenmiş, gerekli ilk analizler yapılmış ve bu verilerden elde edilen anlamlar bir rapor haline getirilerek katılımcılara gönderilmiştir. Katılımcılar kendi raporlarını okuyarak analizlerin kendi gerçeklerini yansıtmadaki doğruluğunu, yeterliliğini ve sonuçların kendi algılarını ve deneyimlerini yansıtıp yansıtmadığını değerlendirerek düşüncelerini bir "teyit toplantısı" ile sözlü olarak bildirmişlerdir. Sözlü "teyit etme" toplantılarında, Yıldırım ve Şimşek'in (2008) de belirttiği gibi ortaya yeni verilerin çıkabildiği görülmüş ve bu yeni veriler de değerlendirmeye alınmıştır.

\subsection{Geçerlik ve Güvenirlik}

Bilimsel bir araştırmanın değeri, ilgili alana kattıkları ve hayatta karşılaşılan sorunlara getireceği çözüm önerileri çerçevesinde değerlendirilir. Araştırmanın bilimsel olarak kabul görmesi için bu iki amaca hizmet etmenin yanında araştırmanın açık, tutarlı olması ve diğer araştırmacılar tarafindan tasdik edilebilmesi gereklidir. Lincoln ve Guba'ya (1985) göre inandırıcılığın başarılabilmesi uzun süreli etkileşime, derinlik odaklı veri toplamaya, çeşitlemeye, uzman incelemesine ve katılımcı teyidine bağlıdır (Akt., Yıldırım ve Şimşek, 2008). Araştırmacı tarafından görüşmeler esnasında yansıtıcı dinleme tekniğine bağlı kalınarak tarafsız olunmaya çalışılmıştır. Okul yöneticilerinin ve öğretmenlerin herhangi bir etki altında kalmadan kendi deneyimlerini rahatlıkla ve samimi olarak aktarmaları için görüşme esnasında sorulan sorular açık uçlu olarak hazırlanmıştır.

Nitel araştırma sürecinde araştırmacının şahsi deneyimlerinin ve yargılarının görüşmelere etki etmesi söz konusu olabilmektedir. Araştırmacı görüşmeler sırasında yönlendirici olmamaya ve dinlediklerini objektif bir şekilde aktarmaya çalışmıştır. Tüm görüşmeler birinci yazar tarafından birebir düz yazıya aktarılarak her bir katılımcıya elden teslim edilmiş ve onlardan alınan teyitten sonra analiz edilmiştir. Görüşmeler genellikle okulun uygun bulunan rehberlik odasında, öğretmenler odasında ve yöneticilerin odalarında gerçekleştirilmiştir.
Araștırmada güvenilirliğin de odaklandığı kavramlardan biri olan tutarlılığa önem verilmiştir. Araştırmada "olay ve olguların değişkenliğini kabul eden ve bu değişkenliği araştırmaya tutarlı bir biçimde yansıtabilen bir yaklaşım" kullanılarak; tutarlılık, veri toplama araçlarının oluşturulması, verilerin toplanması ve analizi aşamalarında uygulanmıştır (Yıldırım ve Şimşek, 2008, s. 272).

\section{Bulgular ve Yorum}

Suriyeli mülteci öğrencilerin okula uyum sürecine ilişkin öğretmen ve okul yöneticilerinin deneyimlerinin içerik analizlerinde iki tema ön plana çıkmıştır. Araştırmada mülteci öğrencilerin okula uyum sürecine ilişkin "Okula Uyum: Öğretmenlerin ve Öğrencilerin Sorunları”, "Uyum Sürecini Kolaylaştırma Stratejileri" olarak iki tema belirlenmiştir. Bu temalar Tablo 2'de sunulmuştur.

Tablo 2. Suriyeli Mülteci Öğrencilerin Okula Uyum Süreçlerine İlişkin Öğretmenlerin ve Okul Yöneticilerinin Deneyimlerinin Temalart ve Alt Temalart

Tema 1. Okula Uyum: Öğretmenlerin ve Öğrencilerin Sorunları

Dil ve İletişim Sorunları

Çocuklarda Dışlama Eğilimi

Özel Birleştirilmiş Sınıfta Eğitim Verilmesinin Yarattığı Sorunlar

Tema 2. Uyum Sürecini Kolaylaştırma Stratejileri

Akran Mentörlüğü

Deneyimli Suriyeli Öğrencilerin Mentörlüğü

Öğretmen Mentörlüğü

Velilere Mentörlük

3.1. Tema 1. Okula Uyum: Öğretmenlerin ve Öğrencilerin Sorunları

Uyum sürecinde öğrencilerin, öğretmenlerin ve yöneticilerin karşılaştıkları sorunlar "Dil ve İletişim Sorunları", "Çocuklarda Dışlama Eğilimi” ve "Özel Birleştirilmiş Sınıfta Eğitim Verilmesinin Yarattığı Sorunlar" olarak belirlenmiştir.

\subsubsection{Dil ve Illetişim Sorunları}

Suriyeli öğrencilerin eğitim sürecinde öğretmenlerin verdikleri en büyük ve zorlu mücadele, dillerini bilmedikleri bir öğrenci grubuyla iletişim kurma çabalarıdır. Suriyeli öğrencilere eğitim ve öğretim vermeye çalışan Yusuf, Niyazi, Fevzi ve Melike öğretmen tarafindan, öğrencilerle yaşanan iletişim problemlerinden bahsedilmiş; Tahir ve Güler öğretmen tarafindan ise velilerle yaşanan iletişim problemleri vurgulanarak bu kişilerin iletişim kurma konusunda ciddi sorun yaşadıkları ifade edilmiştir. Daha önce karşılaşılmayan bu durumun öğretmenler üzerinde tedirginlik yarattığı belirtilmiştir. Uzun yıllardır öğretmenlik yapan Yusuf ve Niyazi öğretmenlerin aşağıda alıntılanan sözleri, sürecin kolay olmadığını göstermektedir:

Ilk defa farklı kültürden, farklı dilden olan bir sınıfta görevlendirince tedirgin oldum. Öğrencilerle, velilerle nasıl iletişim kuracağımı düşünüyordum çünkü sınıfim 14 Suriyeli mülteci ögrenciden oluşmaktaydl. İletişim en büyük problem oldu, sadece konuşmak değil, anlaşılmak, düşüncelerini ifade etmek... Ögrrencilerle sınıftaki en büyük 
sorunumuz birbirimizi anlama oldu (Yusuf öğretmen ile görüşme, Aralık 2016).

Iletişimde genel olarak sorun yaşlyorum. Mesela anlatabileceğim derdimi anlatmakta zorlanıyorum (Niyazi ögrretmen ile görüşme, Aralık 2016).

Tüm öğretmenlerin ve yöneticilerin ifadelerinde "iletişim" öncelikli bir sorun olarak ortaya çıkmaktadır. Karşılıklı diyalog ve anlaşılma gerektiren bu süreç, öğrencilerin de ciddi sıkıntılar yaşamalarına sebebiyet vermiştir. Fevzi öğretmenin görüşmesinde belirttiği gibi "Illk başta büyük bir dil sorunuyla karşılaştılar. Karşı taraftakini anlayamama, derdini anlatamama sorunuyla karşılaştılar. Çok sıradan sorunlarını bile anlatamadıklarında çocuklar sıkıntıya girdiler" yönündeki tespitleri bu durumu ortaya koyar niteliktedir. Fevzi öğretmen, bu sıkıntıları yaşayan çocukların gerek sosyal gerekse duygusal yönden çöküntüye uğradıklarını belirtilmiştir:

Bazen o kadar basit bir şeyi bile dil bilmemeden dolayı yapamadıkları için çocukların kendilerini çok kötü hissettikleri, zaman zaman ağladikları olmuştur. Dil bilmeme onların haksızlı̆̆a uğramasına da neden oluyor. Haklı olduklar bir konu bile olduğunda kendilerini yeterince ifade edemedikleri için haksızmış edasıyla ağladıkları oluyor (Fevzi ögretmen ile görüşme, Aralık 2016).

Bunun yanında aşağıda görüşleri verilen öğretmenin de üstteki ifadelere paralel sayllabilecek fikirler paylaşarak Suriyeli ögrrencilerin kendilerini ifade etme noktasında yaşadıkları sıkıntıları şu şekilde ifade ettiği görülmektedir.

En büyük sıkıntı iletişim. Mesela son gelen öğrencim 1 ay önce falan geldi. Biraz daha geç geldi Lamar. Lamar hiç Türkçe bilmiyor. Diğer iki ögrenci biraz daha biliyor. 3 ögrenci var sınıfta. Lamar hiç Türkçe bilmediği için sınıfta kesinlikle iletişim kuramiyoruz. Son 1 haftadır bir iki kelime çıkıyor. Hareketlerle anlatmaya çalışıyor. Tabi çocuk da kendini kötü hissediyor. Bizim kendimizi kötü hissetmemiz değil, çocuğun kendini kötü hissetmesi. Kendini ifade edemiyor. Ifade edemeyince isteklerini, ihtiyaçlarını dile getiremiyor. Beni hiç anlayamıyor (Melike ögretmen ile görüşme, Aralık 2016).

Eğitimde başarıyı sağlamada en önemli argümanlardan biri olan veli-öğretmen iletişimi, Suriyeli velilerle öğretmenler arasında yaşanan dil problemi nedeniyle sağlıklı bir şekilde gerçekleşememektedir. Bunun sonucunda, Suriyeli öğrencilerin başarısında etkin bir role sahip olan aile fertleri, çocuklarının eğitiminde yeterli katkıyı sağlayamamaktadır. Nitekim Tahir Öğretmen'in görüşmesinde belirttiği "Ailesiyle iletişime geçemedik. İsimlerini bile ögrenemedim" (Aralık 2016) yönündeki tespitleri yaşanan sıkıntıyı ortaya koymaktadır. Aynı şekilde Güler öğretmenle yapılan görüşmede veli- öğretmen iletişim eksikliğinin en önemli sorunlardan biri olduğu belirtilmiştir.

En büyük problemler; okulda yapılan etkinliklerle veya çocuğun durumuyla ilgili olarak Suriyeli velilerin okula gelip ögrretmenle görüşmemeleri oldu. Biz onlar için okulda ne yapabilirsek o (Güler ögretmen ile görüşme, Aralık 2016).

\subsection{2. Çocuklarda Dışlama Ĕ̆ilimi}

Suriyeli mülteci öğrencilerin eğitim sistemine dâhil edilmelerinin ve okula uyum sağlamalarının amaçlandığı bu yeni süreçte, çocuklar gerek müfredat konusunda gerekse davranış boyutlarında dışlanma algısı ile karşılaşmaktadır. Suriye'deki savaş ortamından gelmelerinden ötürü kendilerine karşı oluşan ön yargılar ve dışlayıcı davranışlar, bu öğrencilerin ihtiyaç duydukları psiko-sosyal desteğin eğitim sistemi içinde yeteri kadar karşılanamayışı ve kendilerine uygun eğitim programının bulunmaması, bu öğrencilerin Türk öğrencilerden ayrı bir sınıfta eğitim görmeleri, yaşadıkları maddi sıkıntılar Suriyeli öğrencilerin bu algıyı yaşamalarının sebepleri arasında sayılabilir. Karşılaşılan bu yeni süreçte, gerek öğretmenlerin sorunu çözme konusunda yeterli bilgi ve tecrübeye sahip olamayış1 gerekse yeterli desteği alamayan öğrencilerin kendilerini dışlanmış hissetmeleri onların gruplaşmasına sebep olmaktadır. Uzun yıllardır öğretmen olup şu anda tamamı Suriyeli öğrencilerden oluşan bir sınıfta öğretmenlik yapan Yusuf öğretmen, gruplaşmaya zemin hazırlayan unsurları ve bu durumun sebep olduğu problemleri aşağıdaki şekilde dile getirmektedir.

Okulda ayrı bir mülteci sınıfin oluşturulması, onları ayrıştırmak, dişlamaktır bana göre. Okulda diğer ögrencilerden ayrt bir şekilde sadece Suriyeli mülteci ögrencilerinden meydana gelen bir sinıfin oluşturulması onların gruplaşmasına bir zemin hazırlamıştır. Ayrı mülteci sınıfin oluşturulması diğer öğrencilerle kaynaşma sürecini uzatmıştır. Teneffüslerde ve okul çıkışlarında diğer ögrencilerin ve velilerin de Suriyeli öğrenciler olarak seslenmesi, öğrencileri kendi oyunlarına katmamalart okulda gruplaşmalara yol açmıştır. Bu durum, Suriyeli mülteci ögrencilerin de aralarında gruplaşarak kendi dillerinde oyun oynamalarına sebep olmuştur. Oyun ve fiziki etkinlik dersinde ögrencilerim "ögretmenim Suriyece oynayabilir miyiz?" diyorlardl. Böyle bir sinıfin oluşturulmast sadece ögrenciler arasında değil öğretmenler arasında bile ayrı̧̧malara sebep oluyordu. Düşünsenize aynı okulda ögretmenlerin problemleri genelde aynı şeyler üzerine iken mülteci ögrencilerin ögretmeni olunca o kadar problemle karşllaşıyorsun ki... Suriyeli ögrencilerin ögretmeni olarak Suriyeli Mülteci ögrenciler için ayrıca bir program, yol haritası bulunur diye düşünmüş̧üm ama gördüm ki buna yönelik hiçbir şey yapılmamış. Ülkemizde bu kadar mülteci ögrenci varken onlara yönelik programların olmaması da büyük eksiklik (Yusuf öğretmen ile görüşme, Aralık 2016).

Yine, Yusuf öğretmenle paralel düşüncelere sahip olan Melike öğretmen de dişlanma algısının Suriyeli öğrenciler üzerinde yarattığı olumsuz davranış kalıplarını şu şekilde dile getirmektedir.

Suriyeli olarak bir sınıf oluşturulduğu zaman o sıkıntı yarattı biraz, onlar bir grup oldular ve kendilerini, ayrıştırılmış hissettiler onun için de kendilerini dille de ifade edemediklerinden şiddetle ifade etmeye çalıştılar. Ama bizim sınıfimızdaki Suriyeli öğrenciler diğer arkadaşlarıyla birlikte olduğu için bir sıkıntı yaşanmadı. Okulumuzda bir Suriyeli sinıf var. Suriyeli sinıfin oluşturulmasını ben çok doğru bulmuyorum. Bu belki yaşanarak ögrenilen bir şey belki başta oluşturulurken iyi niyetle oluşturuldu bu sinif, daha kendilerini ifade edebilsinler diye. Ama bu sefer daha iyi ifade edemediler 
çünkü; onlar kendi içlerine kapandllar. Bizim topluluğumuzdan, diğer ögrenci grubumuzdan asimile oldular. Suriyeli grup olarak ortaya çıktılar. Diğer çocuklar onlardan Suriyeli çocuk, Suriyeli sinıf diye bahsediyorlar. Bu sefer onlar iyice hırçınlaşıyor, asileşiyor. Bunun nedeni tamamen kendilerini ifade edememek. Kendilerini şiddetle ifade etmeye başliyorlar (Melike ögretmen ile görüssme, Aralı 2016).

Dışlanma algısına sahip olan ve kendilerini yeteri kadar ifade edemeyen Suriyeli çocukların savaşta yaşadıkları mağduriyetleri paylaşma ve dişa vurma ihtiyacında olduğu, bunu oynadıkları oyunlarla gösterdikleri Güler öğretmen ile Türkan öğretmen tarafindan aşağıdaki şekilde ifade edilmiştir.

En büyük sıkıntı Suriyelilerle ilgili genelde gözlemlediğim, bir başka şey boş zamanlarında sürekli birbirlerini tekmelemek, çekiştirmek üzerine kurulmuş oyunlarl var. Savaş oyunu gibi. Birbirlerini yakalamak, yere düşürmek, yuvarlamak. Tekmeliyorlar. Özellikle görevli olduğum sınıfın katında bunu çok gözlemliyorum (Güler öğretmen ile görüşme, Aralı 2016).

Suriyeli ögrenciler teneffüslerde toplu olarak geziyorlar, kendilerine Suriyeli denildiğinde kavga çıkarmaya çok meyilliler. Teneffüslerde koridorlarda sürekli savaş oyunu oynuyorlar. Ellerinde silah varmış gibi birbirlerini vuruyorlar. Başka oyun oynamıyorlar (Türkan öğretmen ile görüşme, Aralık 2016).

Öte yandan, Suriyeli öğrencilerle Türkiyeli öğrenciler arasında çok kısıtlı iletişim olduğu, arkadaşlık kurulamadığı ve Suriyeli mülteci çocukların etiketlenerek dışlandığı Türkan öğretmen tarafından aşağıdaki söylemlerle ifade edilmektedir.

Suriyeli ögrenciler Türkiyeli ögrrenciler tarafindan dışlanıyorlar. Bir açıdan iletişim kurulamadı̆̆ için dışlanıyorlar, bizi anlamıyorlar diye söylüyorlar. Suriyeli ögrenciler dĭger arkadaşlarlyla bir araya geldikleri zaman saldırganlık gösterdikleri için, sinıftaki öğrenciler de onlarla pek iletişime geçmek istemiyorlar (Türkan ögretmen ile görüşme, Aralık 2016).

Suriyeli mülteci öğrencilerin büyük bir bölümü hem eğitim hem de diğer alanlarda yaşadıkları maddi sıkıntılar nedeniyle okul tarafindan belirlenen k1lık kiyafet kurallarına riayet edememektedir. $\mathrm{Bu}$ durum da Suriyeli çocukların hem kendilerini diğer öğrencilerden ayrı ve eksik görmesine, hem de diğer öğrenciler tarafindan etiketlenerek dışlanmasına sebep olmaktadır. Konuyla ilgili olarak okul müdiresi Billur'un gözlemleri şu şekildedir:

Suriyeli ögrenciler okula ilk başladıklarında, çocuklar birbirlerine karşı çok acımasız oldukları için Suriyeli ögrenciler diye çok tepki gösterenler vardl. Kllık klyafet anlamında da okul kurallarına riayet edemedikleri için, maddi sıkıntıdan dolayı ilk etapta kendi serbest klyafetleriyle geldiler. Bu da bahçede, koridorda ayr olmalarına sebep oldu. Dışarıda ögrenci grupları arasında küçük tartışmalar yaşanıyordu. Çocuklar hemen geliyordu, ögretmenim; Suriyeli ögrenciler bizi dövdü, şunu yaptı bunu yaptı diye şikâyet anlamında yükselişler oluşmaya başladı. Bunu ortadan kaldırmak için gerekli yerlere müracaat ettik. Okul aile birliğimizle de destekleyerek ilk etapta aileleriyle de konuşarak tabi ki. Öncelikle diğer çocuklarla ayrılmayacak duruma getirilerek okul kıyafetleri alındl. Herkes bir ait olma durumu yaşadı böyle olunca. Kendilerini burada mutlu hissetmeye başladılar. Sonra o söylem yıkıldı. Hatta yeni nakil gelen Diyarbakırlı bir ögrencimiz vardl, ögrenciler ilk etapta klyafetlerini tamamlayamadı $\breve{g}_{l}$ için yaptığ hareketlerden dolayı onu bile Suriyeli ögrenci diye şikâyet ettiler. Yani Suriyeli ögrrenci olmak kllı klyafetiyle yorumlanmaya başlandı. Böyle enteresan şeyler de yaşamıştık (Billur müdire ile görüşme, Aralık 2016).

Ayrımcılığa dair öğretmenlerin yaptığı bir paylaşım da Türkiyeli çocukların velilerine ilişkindir. İlk başlarda veliler kendi çocuklarının Suriyeli mülteci çocukların yanında oturmasını istemezken, sonrasında öğretmenlerin çabaları ve karşılıklı etkileşimlerle bu kapalı ve soğuk tavırlarının değiştiği gözlemlenmiştir. Müdür yardımcısı Esat'ın görüşmesinde belirttiği "Velilerin onlara bakış açıları ilk başlarda daha kapall, soğuktu. Ancak her geçen yıl bu biraz daha aşılmakta" yönündeki tespitleri bu durumu ortaya koyar niteliktedir.

\subsection{3. Özel Birleştirilmiş Sinıfta Eğitim Verilmesinin Yarattığ Sorunlar}

Suriyeli mülteci öğrencilerin eğitime entegrasyonunun önemli sorunlarından biri de yaş problemidir. Eğitim sürecinde, fiziksel, duygusal, psiko-motor açıdan farklı özelliklere ve farklı yaş gruplarına sahip olan Suriyeli mülteci öğrenciler için ya ayrı bir sınıf oluşturulduğu ya da bu öğrencilerden bazılarının kendilerinden yaşça küçük Türk öğrencilerin sınıflarına kaydedildiği gözlemlenmiştir. Her iki durumun da kendi içerisinde sakıncalar yarattığı birçok öğretmen tarafından ifade edilmiştir. Her çocuğun okula uyum sağlamada öğrenme olgunluğuna ve okul olgunluğuna sahip olması gerekmektedir. Ayrı bir sınıfta ders gören farklı yaş gruplarına ait Suriyeli öğrencilerin algıları da farklı olduğundan, öğretmenin dersi anlatmada, öğrencilerin de anlatılan dersi istenilen ve beklenilen derecede anlamada problemlerle karşılaştığı görülmektedir. $\mathrm{Bu}$ durum da bu öğrencilerin yıl boyunca aynı seviyede ilerleyememelerine neden olmaktadır. Konuyla ilgili olarak tamamı Suriyeli öğrencilerden oluşan sınıfın öğretmeni Yusuf gözlemlerini şu şekilde dile getirmiştir.

Sinıftaki ögrrencilerin yaşlarl ve fiziksel gelişimleri birbirinden çok farklı idi. Mesela Suriye de 3. sinıfi bitiren bir ögrenci buraya gelince 1. sinıftan okula başlatılmış. Kardeşi de aynı sınıfta olan Muhammed 11 yaşında iken aynı sınıfta okuduğu kız kardeşi 7 yaşında. Herhalde ailesi kardeşine yardımcı olsun diye beraber okula göndermiş. Duygusal, zihinsel ve fiziksel gelişimleri farkl olan çocukların aynı sınıfta eğitim görmesinin olumsuz sonuçları tabi ki kaçınılmaz oluyor. Farklı ögrenme olgunluğuna sahip ögrencilerle aynı ders işlendiğinde çocukların algı kapasitesinin farkl olması nedeniyle istenilen başarının ve faydanın să̆lanması da zorlaşlyor (Yusuf öğretmen ile görüşme, Aralık 2016).

Kendilerinden yaşça küçük Türk öğrencilerle aynı sınıfta okuyan Suriyeli öğrenciler yönünden de yukarıda açıklanan benzer sıkıntılar yaşanmakla birlikte, bu öğrencilerin Türk öğrencilerle yaşadıkları iletişim problemlerinin ve dışlanma algısının da olduğu göz önüne alındığında, bu durum mülteci öğrencilerde birtakım şiddet eğilimlerine de sebep 
olmaktadır. Konuyla ilgili olarak sınıflarında birkaç Suriyeli öğrenci bulunan sinıf öğretmenleri Aslan ve Melike'nin gözlemleri şu şekildedir.

Bu çocukla ilgili şöyle bir sorun yaşlyorum, bu çocuk sınıftaki arkadaşlarından 2 yaş daha büyük. Dolayısıla çocuk fiziki açıdan daha iri, birazcık sınıfta diğer çocuklara şiddet uyguluyor gibi, ama çok fazla rahatsız edici değil de şikâyet konusu oluyor. Onun dişında çocuğun uyum süreciyle alakalı sorun yaşamadık (Aslan öğretmen ile görüşme, Aralık 2016).

Bu okulda gördüğüm çocuklar yaş gruplarına konulmuyor. Mesela 1/E sınıfinda Muhammet var. Çocuk, sinıftaki diğer ögrrencilerden büyük. Belki de 3. sinıf düzeyinde. Bu sefer o çocuk kendini o sınıfta ifade edemiyor ve şiddet göstermeye başllyor (Melike ögretmen ile görüşme, Aralık 2016).

Yapılan araştırma sonucunda, Suriyeli mülteci öğrenciler yönünden eğitim sürecinde yaşanan yaş probleminin önemli sebeplerinden biri, bu öğrencilerin okullara kayıtları sırasında denklik belgesi alma zorunluluğunun uygulanmamasıdır. Bundan dolayı kayıt esnasında veli beyanlarının dikkate alındığı, velilerin beyanlarının da çocuğunun seviyesinin ve yaşının altındaki sınıflara kaydedilmesi yönünde olduğu, okul yönetiminin de bu talebe göre hareket ettiği gözlemlenmiştir. Bu durum, okul müdiresi Billur ile yapılan görüşmede aşağıdaki şekilde ifade edilmiştir.

Okul yönetimi olarak yaşadığımız en büyük sıkıntı, Suriyeli ögrencilerin velileri tarafindan çocuklarının seviyelerinin Suriye'de okuduklart seviye gruplarını altında söylenmesidir. Yani çocuk 5. sinıf ögrrencisiyse bu çocukların Türkçeyi ögrenebilmeleri amacıyla kayıt esnasında 3. sinıf, 2. sinıf deniyor. Bu durum bizi çok zorladı. Yurt dışından gelen yabancı uyruklu öğrencilerin öncelikle denklik almaları gerekiyor. Onlar bu denkliği tabi milli eğitimden de şöyle bir durumla karşılaştık; sonradan da bunları ilettik temel eğitim safhasını bitirmiş olan ögrenciler ortaokula gitmeleri gerekiyor, yani ikinci $4 \ddot{u}$ okumalarl gerekiyor. Ama buraya kendi rizalarlyla gelen, temel eğitim yaşını tamamlamış olan öğrenciler oldu birkaç tane, onlar açısından da zorluklar yaşandı, sınıf ortamındaki diğer öğrenciler açısından da zorluklar yaşandl. Çünkü ailenin talebi; 12 yaşındaki bir öğrencinin 1. Sınıf seviyesinde ĕgitim almasıydı, 1. Sinıfa yazdırma yönünde oluyordu. Denklik olayında da velinin beyanına ĕ̌ilim gösterildiği için ki düzeltildi daha sonradan bu. Yaş oranına da bakılması gerektiği ve Suriye'de ki ĕgitim seviyesinin en azından bir alt derecesine yerleştirilmesi gerektiğini bizler vurgulamaya çalıştık. $O$ anlamda da şu an sıkıntılarımız yok (Billur müdire ile görüşme, Aralık 2016).

\subsection{Tema 2. Uyum Sürecini Kolaylaştırma Stratejileri}

Öğretmenler ve yöneticilerin okula uyum sürecini sağlamada kullandıkları stratejiler "Akran Mentörlügüu”, "Deneyimli Suriyeli Öğrencilerin Mentörlüğü’, "Öğretmen Mentörlüğ̈̈”, "Velilere Mentörlük” olarak belirlenmiştir.

\subsubsection{Akran Mentörlüğ̈̈}

Eğitim sistemlerinin en önemli amaçlarından biri, bazı öğrencilerin diğer öğrencilerden ayrı olarak eğitim görmesinden ziyade, bütün öğrencilerin beraberce eğitim görmesi, etkin bir şekilde eğitime katılması, bir başka ifadeyle, bu öğrencilere okula aidiyet duygusu kazandırılarak hedeflenen düzeyde gelişimini ve öğrenmesini sağlamaktır. Bu amacın gerçekleştirilmesi ise okullarda bütünleştirici kültürlerin var olmasına bağlıdır. Bütünleştirici kültüre sahip olan okullarda farklılık bir sorun olarak değil, bütünlüğü ve uygulama zenginliğini artıran bir firsat olarak görülür ve buna yönelik olumlu duygu, düşünce ve davranışlar geliştirilir.

Yapılan araştırmada, ifadesine başvurulan yönetici Billur ile ögrretmenlerden Melike, Yusuf ve Niyazi tarafindan, Suriyeli mülteci öğrencilerin okula aidiyet duygusu kazanıp en iyi şekilde gelişiminin ve öğreniminin sağlanabilmesi adına bu öğrencilerin akranlarıyla iletişim ve paylaşımlarının geliştirilmesine önem verildiği ve bu amaca yönelik adımlar atıldığı dile getirilmiştir. Konuyla ilgili olarak sınıflarında birkaç Suriyeli öğrenci bulunan sınıf öğretmeni Melike'nin uygulamalarının şu şekilde olduğu ifade edilmiştir.

Sinıfimda Muhammet, Lamar ve Ehlem adında üç tane Suriyeli öğrencim var. Bu ögrencilerinin her birinin yanına Türk arkadaşlarını oturttum. Bu şekilde kendilerini geliştirmelerinin daha kolay olacă̆ını düşündüm. Üçünü çok yalnız bırakmıyorum. Çünkü yalnız kaldıklarında ayrı bir grup oluyorlar. Bu nedenle sinıfa adapte olamayacaklarını düşünüyorum. Onun için Türk arkadaşlarıla vakit geçirmeleri için onlara ön ayak oluyorum. Yaptığımı tüm etkinliklere onların katılmasını să̆llyorum(Melike ögretmen ile görüşme, Aralık 2016).

Diğer taraftan, okul müdiresi Billur da Suriyeli mülteci öğrencilerin Türk öğrencileriyle iletişiminin ve paylaşımının geliştirilmesi için birlikte aynı sınıfta eğitim görmesinin önemine değinerek bu konuyla ilgili uygulamalarını şu şekilde beyan etmiştir.

Aslında ögrencileri kaynaştırma yoluyla, sınıf içerisinde barındırsa mıydık diye düşündüğümüz safhalar da oldu. Acaba daha mı çabuk Türkçeyi ögrrenirlerdi diye düşündüğ̈̈müz. Tabi bu sene onu gözlemleme firsatımız var. Neden diyeceksiniz. Bu sene 6 tane birinci sinif şubemiz var her sinıfta üç ögrenci olmak üzere 18 tane Suriyeli ögrenci var. Yani bizim okul kapasitemize göre bir sinif verebileceğimiz ögrenci mevcut iken, biz onlara kaynaştırma yoluyla eğitim vermeyi seçtik. Suriyeli öğrenci velilerinde de çocuklarının Türk çocuklarlyla birlikte okumalarl, onların tavir ve davranışları neyse daha çabuk almaları yönünde istekleri vardı (Billur müdire ile görüşme, Aralık 2016).

\subsubsection{Deneyimli Suriyeli Öğrencilerin Mentörlüğ̈̈}

Öğretmenlerin ve yöneticilerin Suriyeli mülteci öğrencilerin okula uyum sürecini sağlamada kullandıkları yöntemlerden biri de öğrencilerden faydalanmadir. Okula uyum sürecinde yaşanılan en büyük sıkıntı iletişim problemi olduğundan öğretmenler ve yöneticiler tarafindan öncelikle bu sorunun çözülmesine yönelik arayışlara başlanmıştır. Bu anlamda, Türkçe ve Arapça bilen öğrencilerin tercüman gibi kullanılması, iletişimi sağlamada en etkili ve pratik bir yöntem olarak kullanılmıştır. Bu hususa ilişkin olarak sınıf öğretmenleri Yusuf ve Niyazi şu şekilde beyanlarda bulunmuşlardır. 
Öğrencilerle tanışma babında sorular sordum, yaşını kaç kardeş olduğunu buraya ne zaman geldiklerini, anne babasının ne iş yaptığını... Fakat beni anlayan 4- 5 kişiydi. Diğer öğrenciler Türkçeyi biraz anlasa da Türkçe konuşamıyordu. Türkçeyi daha iyi anlayan ve anlatan ögrenciler benim sorduğum soruları Arapça arkadaşlarına söylüyordu. Arkadaşlarının söylediklerini de Türkçeye çevirip bana iletiyordu. Illetişim en büyük problem oldu. Okumayı ögrencilerin çoğu ögrenmiş olmasına karşı anlamlarını bilmiyorlardı. Bu yüzden bir kelime söylerken anlamını açıklıyordum. Türkçeyi anlayan öğrenciden de diğer ögrencilere anlatmasını istiyordum. Sınıfta sürekli Arapça konuşuyorlard, sınıfta Arapça konuşmayı yasak ettik, sadece bazı ögrencilere tercümanlık yaparken serbest bıraktık (Yusuf öğretmen ile görüşme, Aralık 2016).

Iletişimde genel olarak sorun yaşlyorum. Geçen seneden tekrar yapan ögrencim bu konuda diğer 2 ögrenciye göre daha iyi, onunla iletişim kurup diğerleriyle iletişim kurmasını istiyorum (Niyazi ögretmen ile görüşme, Aralık 2016).

Türkçe ve Arapça bilen öğrenciler sadece öğretmen-öğrenci iletişimini sağlamakla kalmayıp aynı zamanda veliöğretmen ve idareci arasındaki iletişimi sağlamada da etkin bir rol oynamıştır. Konuyla ilgili olarak sınıf öğretmeni Aslan ve müdür yardımcısı Esat'ın beyanları şu şekildedir.

Ailesiyle iletişime şöyle geçebiliyorum; bu çocukla ilgilenen dedesi var, dedesi de Suriye'de ögretmen olduğunu söylüyor. Dönem dönem geliyor, annesini bir iki defa gördüm babasını hiç gelmedi. Dedesini 5-6 defa gördüm. Dedeyle 3. sınıfta okuyan küçük bir kız çocuğunun Türkçesi çok iyi onun vasitastyla görüşüyoruz (Aslan öğretmen ile görüşme, Aralı 2016).

2014 yllında tek aile olarak okulumuzda iki ögrrencisini bulunduran kişiden ve ögrencilerinden çok büyük yardım aldık. Çünkü onlar Türkçeyi baya ögrenmişlerdi. Birisi o zaman 4. sınıfa diğeri de 1. sinıfa gidiyordu. Çocukların ikisi de Türkçeyi baya ögrenmişlerdi. Okulumuzda diğer çocuklarla anlaşırken veya velileriyle anlaşırken onları tercüman gibi kullandik. Çocuklardan biri hala okulun ögrencisi ve zaman zaman kendisinin dil bilme avantajından faydalanıyoruz (Esat müdür yardımcısı ile görüşme, Aralık 2016).

Eğitim sürecinde, öğrenciler rol model olarak benimsedikleri öğretmenleri ve akranları sayesinde dili kullanma ve anlama, öğrenme, muhakeme etme, sorun çözme ve karar verme gibi zihinsel süreçlerine ilişkin becerilerini geliștirebilir; yeni değerler ve inançlar kazanabilir. "Rol model" kavramının Suriyeli mülteci öğrencilerin okula uyum sürecini hızlandırmada etkili bir yol olacağı kanaatinde olan Melike öğretmen bu yöntemi uygulama şeklini şu şekilde dile getirmiştir.

Sınıfimda mevcut olan üç tane Suriyeli ögrenciyi aynı sıra grubuna koymadım. Her birini ayr sira grubunda, kendilerini iyi ifade edebilen, özgüveni yüksek Türk ögrencilerle birlikte oturttum. Buradaki amacım bu ögrencileri kendilerine rol model olarak almaların sağlamaktı. Bu şekilde uyum sürecinin daha hızlı ve sağlıklı ilerleyeceği kanaatindeyim (Melike ögretmen ile görüşme, Aralık 2016).

\subsection{3. Öğretmen Mentörlü̆̆̈̈}

Eğitim sürecinde birçok sorunla karşılaşan Suriyeli mülteci öğrencilerin okulu benimsemelerine, sevmelerine, kendilerini rahat ifade edebilmelerine, diğer öğrencilerle etkileşimlerinin artırılarak sosyalleşme sürecine yardımcı olmak; sosyal, kültürel, zihinsel ve fiziksel gelişmelerine katkı sağlamak için serbest etkinlik çalışmaları dersi büyük önem taşımaktadır. Bu ders kapsamında öğrencilerin ilgi ve ihtiyaçlarına yönelik pek çok etkinliğe yer verilebilir. Yapılan etkinlikler, mülteci öğrencilerle Türk öğrencilerin kaynaşmasına, yardımlaşma ve dayanışma özelliklerinin gelişmesine yardımcı olacağı gibi öğrencilerin sosyal çevrelerini tanıyabilmelerine, yaşadıkları sorunlara çözümler getirebilmelerine, toplum ile uyumlu ve topluma katkı sağlayabilen bireyler olarak yetişmelerine de imkân sağlayacaktır. Suriyeli mülteci öğrencilerin okula uyum sürecinde yaşanan en büyük sorunlar "dil ve iletişim sorunları" ve "çocuklarda dişlama eğilimi" olduğundan, serbest etkinlik çalışmaları dersi öğretmenlerin bu sorunlara çeşitli çözüm yolları bulmasında büyük önem taşımaktadır. Konuyla ilgili olarak sınıf öğretmeni Yusuf bu dersi değerlendirme şeklini şu şekilde dile getirmiştir.

Okuma yazma öğrenemeyen, iletişimde sorun yaşadığımız ögrencilerle serbest etkinlik derslerinde okuma yazma çalışmas yapıyoruz. Akranlarıyla kaynaşabilmeleri ve kendilerini daha mutlu hissedebilmeleri için onlara mendil kapmaca, istop, yakan top alışmaları daha kolay oluyor gibi çeşitli oyunlar oynatıyorum. Bu dersler sayesinde okul ortamına alışmalarl daha kolay oluyor akademik gerekse sosyal anlamda yaşadıkları zorlukları ve bu zorlukların psikolojilerinde yarattı̆g olumsuz etkileri, serbest etkinlik çalışmalar dersinde yaptığımız etkinliklerle telafi etmeye çalışıyorum. Bu şekilde bu çocukların daha mutlu ve özgüveni yüksek bireyler olarak yetişmelerine katkl sağlanacă̆ kanaatindeyim (Yusuf ögretmen ile görüşme, Aralık 2016).

Serbest zaman etkinlikleri yoluyla sağlanan öğretmen mentörlüğünün yanında eğitim ve öğretim etkinliklerinin tüm süreçlerinde öğretmenlerin mentör rolünü üstlenmeleri beklenmektedir. Görüşme yapılan öğretmenler tarafindan aktarılan deneyimler, ders sırasında kullanılan öğretim yöntemlerinde öğrencinin merkeze alındığı ve öğretmenin mentör rolünü üstlendiği durumların öğrencilerin öğrenme deneyimlerine olumlu yansıdığını göstermektedir. Suriyeli öğrencilerin okula uyum sağlaması sorunuyla karşılaşan öğretmen ve yöneticiler, eğitim programlarında belirlenen amaçlara ulaşmak için dersi işleme tekniklerinde öğrencilerin algılama düzeyine göre farklı yöntemler geliştirdiklerini ifade etmişlerdir.

Türkan öğretmen, öğrencinin derste aktif olmasını sağlama yönünde bir yöntem izlemiştir. Konuyla ilgili beyanı şu şekildedir.

Biz kendimiz sınıfta her türlü olayın içine çocukları katmaya çalışıyoruz. Öncelikle Türkçe konuşmayı öğrenmeleri adına sürekli onlarla konuşmaya çalışıyorum, tahtaya kaldırıyorum. Derste konuşturmaya çalıştırlyorum (Türkan ögretmen ile görüşme, Aralık 2016).

Yusuf ögrretmen, beden dili kullanılan ve görsellerle desteklenen bir anlatım şeklini izlemiştir. Ders işleme tekniğini şu şekilde dile getirmiştir. 
Öğrencilerle sinıftaki en büyük sorunumuz birbirimizi anlama oldu. Okumayı öğrencilerin çoğu öğrenmiş olmasına karşı anlamlarını bilmiyorlardı. Bu yüzden bir kelime söylerken beden dili kullanarak ve görsellerle destekleyerek anlamını açıklıyorum (Yusuf ögretmen ile görüşme, Aralık 2016).

Gülhanım öğretmen, anlaşılamayan kelimelerin anlamlarını çeviriden yararlanarak anlatmayı seçmiş ve bunu şu şekilde ifade etmiştir.

Suriyeli öğrencilerimin Türkçe karşılı̆̆ını bilmediğ kelimeleri Google Translate' den Arapçaya çevirerek anlatmaya çallştım (Gülhanım ögretmen ile görüşme, Aralık 2016).

Okul müdürü Billur Suriyeli öğrencilerle ders işlemede görsel anlatımın ve etkin katılımla "yaparak yaşayarak öğrenme"nin önemine şu sözlerle vurgu yapmıştır.

Ücretli bir sınıf ögretmeni arkadaşımız Suriyeli öğrencilerimizle yaşadı̆̆ dil problemini çözmek için ciddi çabalar sarf etti. Öğretmen Arapça bilmiyor, çocuklar Türkçe bilmiyor, bir iki çat pat Türkçe bilenler var onlarla yolaçıktı, çokçabasarf etti ama güzel çalışmalar da yaparak olumlu sonuçlar elde etti. Duvarlara birçok kartondan, kâğttan onların anlayabileceği resimlendirerek, yanına Türkçesini yazarak sürekli görsel olarak bir şeyler yapmaya çalıştı. Projeksiyon cihazıyla da çalışmalar yürüttü zaten. Okuduklarını anlamak onlar için çok zor. Bunu yıkabilmek için de görselliği ve uygulamayı hayatın içerisine ya da ögrettiğiniz konuların içerisinde bunlara yer vermek gerekiyor diye düşünüyorum, benim gözlemim bu. 1. Sinıftayken şu an 2/f olan sinıfimız için konuşuyorum, ücretli ögretmen olan arkadaşımız dişarlya bahçeye de çıkarttı, uygulamalı olarak her şeyi; işte bir peçete dediğinde neyin olduğunu net olarak anlayabilmek için, onu göstererek dokundurarak bütün duyu organların kullanarak çalışmalarını gerçekleştirdi. Yani düz anlatım şeklinde değil. Zaten sınıf ortamında diğer çocuklara anlatırken de tekdüze değil. Her türlü duyu organını kullanmaniz gerekiyor zaten ama Suriyeli olan öğrencilerimize özel olarak daha fazlası yapılmaya çalışıldı (Billur müdire ile görüşme, Aralık 2016).

Songül öğretmen, ders işlerken yavaş konuşarak ve anlaşılmayanı tekrar ederek ders işlediğini şu şekilde beyan etmiştir.

Ama ben bir şeyler söylediğim zaman birebir iletişimde daha yavaş konuşuyorum. Anladın mı diye de soruyorum tekrardan. Genelde anladım diyor (Songül ögretmen ile görüşme, Aralık 2016).

\subsubsection{Velilere Mentörlük}

Eğitimde başarının yakalanması öğretmen-öğrenci ilişkisinin etkin bir şekilde kurulmasının yanı sıra öğretmen-veli iletişiminin de sağlıklı bir şekilde kurulmasına bağlıdır. Veli ile öğretmen arasında iş birliği sağlanamadıkça sürdürülebilir bir başarı elde etmek mümkün değildir. Jencks ve arkadaşları'nın (Malkoç, 1993) yaptığ okuldaki başarısını etkileyen en önemli çevre faktörüdür. $\mathrm{Bu}$ araştırmadan çıkarılan sonuçlara göre, öğrencinin okuldaki başarısının yarıdan fazlası ailenin katkısı ile gerçekleşmektedir. Suriyeli veliler ile öğretmenler arasında yaşanan iletişim kopukluğu nedeniyle öğretmen ve aile, çocuğun eğitimi konusunda gereken iş birliğini gösterememekte, bu durum da çocuğun başarısını olumsuz yönde etkilemektedir. Bu sorunun farkına varan yöneticiler velilere okuma-yazma kursu açarak aralarındaki iletişim engellerini aşmaya çalışmışlardır. Konunun önemine değinen sınıf öğretmenleri Yusuf ve Gülhanım'ın ifadeleri şu şekildedir.

Okul idaresi mülteci velilere yönelik Türkçe okuma- yazma kursu açtı. Bu şekilde veli-ögretmen ilişkisinin günden güne gelişeceğini, bunun da çocuğun başarısına olumlu katkı sağlayacağını düşünüyorum (Yusuf ögretmen ile görüşme, Aralık 2016).

Suriyeli öğrencilerin ailelerine okul çıkışı okuma yazma kursu veriyorum. Bu kurs sayesinde birbirimizi daha iyi anlamaya başladık. Bu şekilde çocuğun eğitimi konusunda aramızdaki engeller de aşıllyor (Gülhanım ögretmen ile görüşme, Aralık 2016).

\section{Tartışma, Sonuç ve Öneriler}

Bireyin içinde bulunduğu toplumda kendisini ifade etmesinin, toplumdaki diğer bireyler ile iletişim kurmasının ve etkileşim sağlamasının temel aracının dil olduğu düşünüldüğünde; dil farklılığının hem mülteciler hem de ülke vatandaşları için birçok sorunu da beraberinde getirdiği görülmektedir (Uzun ve Bütün, 2016). Yapılan çalışmada, Suriyeli mülteci öğrencilerin okula uyum sürecinde karşılaştığı en önemli sorunun dil ve iletişim problemi olduğu ifade edilmiştir. Kiremit, Akpınar ve Akcan (2018) tarafından gerçekleştirilen araştırmanın bulguları da bu araştırmayı desteklemektedir. Araştırmacılar yapmış olduğu çalışmada, Suriyeli öğrencilerin Türkçe bilmediklerinden, öğretmenlerin Suriyeli öğrencilerle iletişim kuramadığını ve onları eğitim-öğretim sürecine katamadığını tespit edilmiştir (Kiremit, Akpınar ve Akcan, 2018). Araştırmacıların elde ettiği bu bulgular bu araştırmanın bulguları ile de örtüşmektedir. Benzer bir şekilde Bulut, Soysal ve Gülçiçek (2018) tarafından yapılan araştırmanın bulguları da bu araştırmanın bulguları ile örtüşmektedir. Araştırmacılar, yabancı öğrencilerin dil sorunlarına nasıl çözüm getireceklerini bilmedikleri, yabancılara Türkçe öğretimi konusunda herhangi bir eğitim sürecinden geçmedikleri ve Suriyeli öğrencilerin Türkçe bilmedikleri için büyük sorunlar yaşadıkları sonucuna ulaşmışlardır (Bulut, Soysal ve Gülçiçek, 2018). Araştırmacıların elde ettikleri bu sonuçlar bu araştırmanın bulgularını da desteklemektedir. Yine bu araştırmanın bulguları ile örtüşen başka bir araştırma Güven ve İşleyen (2018) tarafından gerçekleştirilmiştir. Araştırmacılar yapmış oldukları araştırmanın sonucunda, Suriyeli öğrencilerin dersine giren öğretmenlerin çoğunun dil farklılığı yüzünden bu öğrencilere istenilen eğitimi veremediklerini ve iletişim kurmakta güçlük yaşadıklarını dile getirdiğini tespit etmiş̧tir. Araştırmacıların elde ettiği bu neticeler, bu araştırmanın bulguları ile de örtüşmektedir.

Dil engeli nedeniyle, çocuklar akranları ve öğretmenleri ile iletişim kurma, kendilerini ifade etme noktasında çok büyük sıkıntılar yaşamakta, bu çocuklarla ve aileleriyle iletişim kuramayan öğretmen ve idareciler de sorun çözme konusunda kendilerini yetersiz hissetmekte ve bu engeli aşma adına farklı stratejiler kullanmaya çalışmaktadır. İletişim problemi bir domino etkisi yaratarak beraberinde 
birçok sorunu da getirmektedir. Dil engeli çocukların kendilerini net ifade edememelerinden dolayı içlerine kapanmalarına, diğer çocuklar ile uyum sağlayamamalarına, yalnız kalmalarına ve saldırgan davranışlarda bulunmalarına sebep olabilmektedir (Yohani, 2010).

Suriyeli öğrencilerin eğitime uyumunun sağlanmasında tespit edilen bir diğer problem de bu öğrencilerin dışlanarak ötekileştirilmesidir. Araştırmanın bu bulgularını, Bulut, Soysal ve Gülçiçek (2018) tarafından yapılan araştırmanın sonuçları da desteklemektedir. Zira, araştırmacılar, sığınmacı öğrencilerin kendi aralarında gruplaştığını ve bu öğrencilerin sınıfta dışlandığını, Suriyeli öğrencilerin ötekileştirildiğini ifade etmektedir. Kiremit, Akpınar ve Akcan (2018) da yapmış oldukları araştırmada, Suriyeli öğrencilerin akranları tarafından kabul görmediğini, dışlandığını ve etiketlendiğini dile getirmektedir. Araştırmacıların ulaştığı bu sonuçlar bu araştırmanın bulguları ile de benzeşmektedir. $\mathrm{Bu}$ durumun temelinde kültür farklılığı ve ön yargıların olduğu düşünülmektedir.

Bilindiği üzere yerleşik bir topluma dışarıdan yeni bir grup geldiği zaman bu kesim istenen düzeyde toplumun içine dâhil edilmeyebilmekte ve dişlanma problemleri gündeme gelebilmektedir (Adaman ve Keyder, 2006). Dolayısıyla sosyal dişlanma çoğu zaman göç olgusundan sonra ortaya çıkmakta ve göçmenler toplumdan dişlanma potansiyeliyle var olmaktadır. Bazı mülteci gruplar, özellikle etnik ve dinsel benzerlik sebebiyle daha sıcak karşılanabilirken diğerleri ise, farklı kültürel geçmişlerinden dolayı o toplum tarafindan kabul edilmeyebilir ve dişlanabilir. $\mathrm{Bu}$ durum kimi zaman deri rengi gibi rrksal sebeplerden, kimi zaman da dinsel farklılıklardan dolayı ortaya çıkabilmektedir (Ciğerci, 2012). Dolayısıyla dilsel ve kültürel farklılıklar dişlanmaya sebep olabilmektedir. Suriyeli göçmenler için de bu şekilde bir dişlanma söz konusudur. Türkiye ile Suriye toplumunun dilsel ve kültürel farklılara sahip olmaları, göç sürecinde de dışlanmanın sebeplerinden olabilmektedir. Yapılan çalışmada, eğitimde iletişim probleminin, beraberinde "Çocuklarda Dişlama Eğilimi" sorununa, bir başka ifadeyle dışlanma algısına zemin hazırladığı tespit edilmiştir. Eğitim sürecinde dışlanma algisını yaratan en temel unsur dil engeli olmakla birlikte, Suriye'deki savaş ortamından gelen bu çocuklara karşı Türk öğrencileri ve velileri tarafindan sahip olunan önyargılar ve ayrımcı davranışlar, eğitim sistemi içinde yeteri kadar psikososyal destek görememe, yaşadıkları maddi sıkıntıların okul ortamına da yansıması diğer unsurlar olarak görülmektedir.

Suriyeli mülteci öğrencilerin okula uyum sürecinde karşılaşılan başka bir problem de farklı yaş gruplarına ait olan Suriyeli öğrencilere aynı sınıfta ders verilmesi, kendilerinden yaşça küçük Türk öğrencilerin sınıflarına kaydedilmesidir. Araştırmaya katılan öğretmenler, farklı yaş gruplarına ait olan bu çocukların öğrenme olgunluğunun farklı düzeylerde olması nedeniyle, çocuğun anlatılan konuyu istenilen ve beklenilen derecede anlayamadığını ve algı düzeyleri farklı olan bu çocuklara dersi anlatma, sınıf disiplinini sağlama gibi konularda zorluklar yaşandığını dile getirmektedir. Aykırı (2017) tarafindan yapılan araştırmanın bulguları da bu araştırmanın bulgularını desteklemektedir. Zira Aykırı, yaptığı çalışmasında Suriyeli öğrencilerin okula uyum sürecinde öğretmenlerin en çok karşılaştığı problemlerden birisinin de farklı yaş grubundaki ögrencilerin aynı sınıfta ders yapmak zorunda kalması olduğu sonucuna ulaşmıştır (Aykırı, 2017). Araştırmacının ulaştığı bu sonuçlar bu araştırmanın sonuçları ile de paralellik göstermektedir. Farklı yaş gruplarına ait olan Suriyeli öğrencilere aynı sınıfta ders verilmesi durumunda, bu çocukların öğrenme olgunluğunun farklı düzeylerde olması nedeniyle, çocuğun anlatılan konuyu istenilen ve beklenilen derecede anlayamama sorunu gündeme geleceği gibi, öğretmenler yönünden ise algı düzeyleri farklı olan bu çocuklara dersi anlatma, sınıf disiplinini sağlama gibi konularda zorluklar ortaya çıkacağı tabiidir. Ayrıştırılmış sınıflarda verilen eğitimde karşılașılan sorunlar gündeme gelmekle birlikte, buna ilave olarak sınıf içerisinde iletişim problemi ve dışlanma algısı yaşayan bu çocukların Türk öğrencilere karşı şiddet eğilimi ortaya çıkmaktadır.

Eğitim sisteminin amacı devlet okullarında çocukların hep birlikte erkin bir şekilde en üst düzeyde eğitim almalarını sağlamaktır (Booth ve Ainscow, 2002; UNICEF, 2015). Yapılan araştırmada, öğretmen ve okul yöneticilerinin, Suriyeli öğrencilerin okula uyumunun en etkin ve üst düzeyde sağlanması adına bütünleştirici okul kültürü yaratma amaciyla hareket ettikleri, bu amaca ulaşmak için de hem bu öğrencilerin akranlarıyla ve öğretmenleriyle iletişim ve paylaşımlarının geliştirilmesine, hem de Suriyeli velilerin okulla iletişiminin sağlanmasına yönelik uygulamalar yaptıkları görülmüştür. Burns, Roe ve Ross (1992) tarafından yapılan araştırmaya göre; ebeveynler ve öğretmenler arasındaki düzenli iletişim büyük bir önem taşımaktadır. Veliler için öğretmenler tarafından hazırlanan ve okuldaki etkinlikleri, ihtiyaçları, kuralları, velinin ihtiyaç duyacağı yardımcı bilgileri içeren broşürler bu iletişimin sağlanması için gerekli olan geleneksel araçlardır. Okul-aile ilişkilerinde uzun yıllardır uygulanan iletişim yolları; öğrenciler ile ilgili kişisel bilgi kartları, öğretmen-veli telefonlaşmaları ve toplantıları, öğretmenlerin ev ziyaretleri, ebeveynlerin çocuklarının sınıf içi etkinlikleri görmelerine imkân sağlayan izleme günleridir. Okul idaresi ile öğretmenlerin vizyon ve tecrübelerinden yararlanılarak okul imkanlarının elverdiği ölçüde Suriyeli çocukları yapılan bütün etkinliklere dahil etme, Türk öğrencilerle aynı sınıfta eğitim vererek kaynaşmalarını sağlama, Türkçe ve Arapça dillerini bilen ögrrencilerden yararlanarak gerek öğrenci-öğretmen gerekse veli-öğretmen ve yönetici arasındaki iletişimi sağlamaya çalışma, "rol model" olabilecek öğrencilerle Suriyeli öğrenciler arasındaki iletişimi kuvvetlendirmeye yönelik adımlar atma, serbest etkinlik çalışmaları derslerinde öğrencilerin ilgi ve ihtiyaçları doğrultusunda çeşitli etkinliklere yer vererek Suriyeli öğrencilerle Türk öğrencilerin kaynaşmasına, yardımlaşma ve dayanışma özelliklerinin gelişmesine yardımcı olma, ders işleme tekniklerinde bu öğrencilerin algılama düzeyine göre farklı yöntemler geliştirme, öğretmen-veli iletişiminin ve devamında işbirliğinin sağlanması adına en önemli engel olan dil problemini aşmak adına okuma-yazma kursu açma gibi uygulamalar, öğretmen ve yöneticilerin Suriyeli öğrencilerin eğitim görmelerinin önünde duran çok boyutlu engelleri bütünleştirici bir okul kültürü oluşturmaya çalışarak tüm paydaşların katılımıyla çözme eğiliminde olduğunu göstermektedir.

Yapılan araştırmadan elde edilen sonuçlara dayanarak şu önerilere yer verilebilir: 
- $\quad$ Suriyeli öğrencilerin okula uyum sürecinde karşılaşılan en önemli sorun, bu öğrencilerle ve velileriyle yaşanan iletişim problemidir. $\mathrm{Bu}$ problemin aşılması adına Türkçe okuma-yazma kurslarının yaygınlaştırılması, okullarda sürekli tercüman hizmeti sunulması gibi sistematik çözümler getirilebilir.

- Öğretmen ve idarecilere bu çocuklara yaklaşım konusunda ve bu çocuklara karşı yapılan ayrımcı davranışlarla baş etme konusunda uygulayabilecekleri yöntemlere ilişkin psikolojik danışma hizmetleri verilebilir.

- Okullarda Suriyeli öğrencilerin akranlarıyla kaynaşmasına yönelik çeşitli proje ve etkinlikler düzenlenebilir.

- Öğretmenlerin ve velilerin bir araya geleceği etkinliklerin düzenlenmesi suretiyle öğretmenlerin velileri, velilerin de öğretmenleri ve birbirlerini yakından tanıma fırsatı sağlanabilir.

- Travmatik deneyimlerden geçerek Türkiye'ye gelen, burada da bir yandan sosyo-ekonomik sikıntılar, gelecek kaygısı gibi sorunlarla boğuşurken diğer taraftan yeni bir dile, müfredata, eğitim sistemine alışmaya çalışan Suriyeli öğrencilerin bu sorunlarını aşmada okullara ve öğretmenlere büyük rol düşmektedir. $\mathrm{Bu}$ bağlamda, farklı eğitsel ve kişisel ihtiyaçları olan çocukların bir arada etkin bir şekilde eğitilmesi için, öğretmenlere ve yöneticilere yeterli kaynaklar sağlanabilir.

- $\mathrm{Bu}$ çalışma daha geniş kapsamda farklı illerde, farklı okullarda da uygulanabilir.

- Yönetici ve öğretmenlerin yanı sıra öğrencilerin görüşlerine de yer verilen daha geniş kapsamlı bir çalışma yapılabilir.

\section{Kaynakça}

Adaman, F. ve Keyder, Ç. (2006). Türkiye'de büyük kentlerin gecekondu ve çöküntü mahallelerinde yaşanan yoksulluk ve sosyal dişlanma. 11.11.2016 tarihinde

http://ec.europa.eu/employment_social/social_inclus ion/docs/2006/study_turkey_tr.pdf. adresinden erişilmiştir.

Aykırı, K. (2017). Sınıf öğretmenlerinin sınıflarındaki Suriyeli öğrencilerin eğitim durumlarına ilişkin görüşleri. Turkish Journal of Primary Education, 2(1), 44-56.

Booth, T. ve Ainscow, M. (2002). Index for Inclusion: Developing learning and participation in schools. 19.05.2020 tarihinde http://www.csie.org.uk/resources/translations/IndexE nglish.pdf adresinden erişilmiştir.

Bulut, S., Soysal, K. Ö. ve Gülçiçek, D. (2018). Suriyeli öğrencilerin Türkçe öğretmeni olmak: Suriyeli öğrencilerin eğitiminde karşılaşılan sorunlar. Uluslararası Türkçe Edebiyat Kültür Eğitim (TEKE) Dergisi, 7(2), 1210-1238.

Burns, C. P., Roe B. D. ve Ross E. P. (1992). Teaching reading in today's elementary scchools. Boston Houghton Mifflin Company.
Ciğerci, N. (2012). Bursa-Kırcaali hattı: 1989'da gelen Bulgaristan göçmenleri örneği. S. G. Ihlamur Öner, N. A. Şirin Öner (Ed), Küreselleşme çă̆ında göç kavramlar, tartışmalar içinde (s. 107-134). İstanbul: İletişim Yayınları.

ÇOÇA (İstanbul Bilgi Üniversitesi Çocuk Araştırmaları Merkezi). (2015). Suriyeli mülteci çocukların Türkiye devlet okullarındaki durumu politika ve uygulama önerileri. 12.11.2016 tarihinde http://www.cocukcalismalari.org/wpcontent/uploads /2015/09/Suriyeli-Cocuklar-EgitimSistemi-PolitikaNotu.pdf adresinden edinilmiştir.

Emin, N. M. (2016). Türkiye'deki Suriyeli çocukların eğitimi SETA. Ankara. 10.11.2016 tarihinde http://file.setav.org/Files/Pdf/20160309195808_turki yedeki-suriyeli-cocuklarinegitimi-pdf.pdf adresinden edinilmiştir.

Güven, S. ve İşleyen, H. (2018). Sınıf yönetiminde iletişim, iletişim engelleri ve suriyeli ögrrenciler. Journal of Social and Humanities Sciences Research, 5(23), 293-1308.

Gresham, F. M. ve Elliott, S. N. (1987). The relationship between adaptive behavior and social skills: Issues in definition and assessment. The Journal of Special Education, 21(1), 167-181.

Hacıfazlıŏlu, Ö. (2010). Yükseköğretimde lider olarak göreve uyum sağlama süreci: Türkiye ve Amerika'dan kadın liderlerin deneyimleri. Kuram ve Uygulamada Eğitim Bilimleri Dergisi, 10(4), 22212273.

Kiremit, R. F., Akpınar, Ü. ve Akcan, A. T. (2018). Suriyeli öğrencilerin okula uyumları hakkında öğretmen görüşleri. Kastamonu Eğitim Dergisi, 26(6), 21392149. DOI: $10.24106 /$ kefdergi.428598

Ladd, G. W. ve Price, J. M. (1987). Predicting children's social and school adjustment following. Developmental Psychology, 58(5), 1168-1189.

Malkoç, G. (1993). Aile eğitimi ve eğitimde nitelik geliştirme, eğitimde arayışlar I. Sempozyumu. İstanbul, Kültür Koleji Yayınları, 10-20.

Mutlu, Y. ve Kırımsoy, E. (2016). Bulanık mekanlarda gölgede kalanlar Suriyeli mülteci çocuklar ve vatansızlık riski araştırma raporu. Gündem Çocuk Derneği. Ankara. 13.11.2016 tarihinde http://www.gundemcocuk.org/belgeler/yayinlarimiz/ kitaplar/Suriyeli-MulteciCocuklar-Ve-VatansizlikRiski-Raporu.pdf adresinden edinilmiştir.

Odman, T. (2008). Çocuk hakları bağlamında çocuk mülteciler. Mersin: Çağ Üniversitesi.

UNCHR. (2016). Sik sorulan sorular. 13.11.2016 tarihinde http://www.unhcr.Org/turkey/uploads/root/s\%C4\%B 1 ksorulansorular.pdf adresinden edinilmiştir.

UNICEF (2015). Türkiye'deki Suriyeli çocuklar bilgi notu. 11.11.2016 tarihinde http://www.unicef.org.tr/files/bilgimerkezi/doc/T\%C 3\%BCrkiyedeki\%20Suriyeli\%20\%C3\%87ocuklar Bilgi\%20Notu\%20Kas\%C4\%B1m\%202015.pdf adresinden edinilmiştir. 
UNICEF (2016). Türkiye'deki Suriyeli çocuklar bilgi notu.

13.11.2016 tarihinde

http://unicef.org.tr/files/bilgimerkezi/doc/T\%C3\%B

Crkiyedeki\%20Suriyeli\%20\%C3\%87ocuklar_Bilgi $\% 20$ Notu\%20Kasim\%202015.pdf. adresinden edinilmiştir.

Uzun, E. M. ve Bütün, E. (2016). Okul öncesi eğitim kurumlarındaki Suriyeli sığınmacı çocukların karşılaştıkları sorunlar hakkında öğretmen görüşleri.
Uluslararası Erken Çocukluk Eğitimi Çalışmaları Dergisi, 1(1).

Yıldırım, A. ve Şimşek, H. (2008). Sosyal bilimlerde nitel araştırma yöntemleri (Güncelleştirilmiş ve geliştirilmiş beşinci baskı). Ankara: Seçkin Yayıncilık

Yohani, S. (2010). Nurturinghope in refugee children during earlyyears of post-waradjustment. Children and Youth Services Review, 32(6), 865-873.

Ek-1: Etik Kurul Onay1

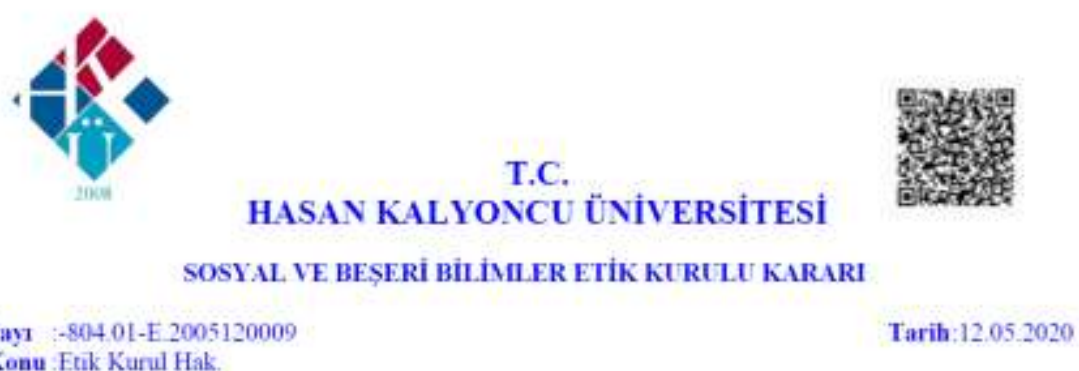

Konu Etik Kurul Hak.

\begin{tabular}{|c|c|}
\hline Cahsmanin Türï: & Bilimsel Calisana (Makale) \\
\hline Konu: & Bilimsel Calısma (Makale) \\
\hline Baylak: & $\begin{array}{l}\text { Maltecilerin Cocuklarin Illkōgérefime Uyum Süreci: Tekirdağda Bir } \\
\text { Okuldan Ogretmen ve Yönetici Deneyimleri" }\end{array}$ \\
\hline Yürüttūcū/Danışman: & Prof Dr. Ozge HACIFAZIIOGLU \\
\hline Yazar: & Caner DINLER \\
\hline Karar: & Olumlu \\
\hline
\end{tabular}

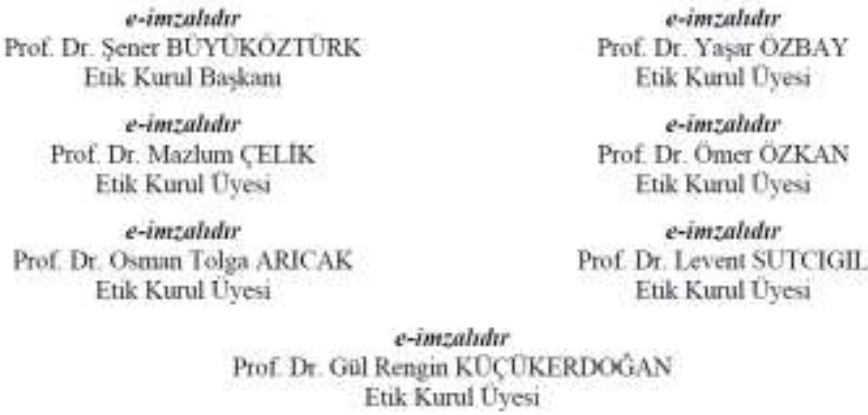

Eki:Caner Diner Etik Kurul pdf (Elektronik Ek)

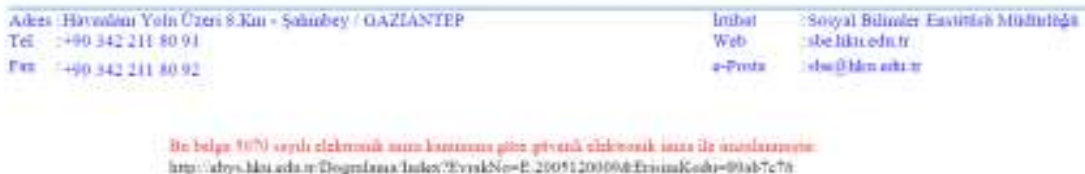

